\title{
KONSTRUKSI AKUNTANSI KERUGIAN, PRAKTIK KEPAILITAN MENGUNGKAPFRAUD LAPORAN KEUANGAN KLIEN
}

\author{
Nahruddien Akbar \\ Universitas Singaperbangsa, Karawang Jabar \\ Email:kjasduc@gmail.com \\ Diterima 17 Mei 2019, Disetujui 20 Juli 2019
}

\begin{abstract}
Abstrak
Tujuan penelitian ini untuk memaknai konstruksi akuntansi kerugian dalam mengungkapkan Fraud dan praktik kepailitan laporan keuangan klien. Metode penelitian digunakan adalah metode kualitatif - paradigma interpretif dengan pendekatan fenomenalogi dengan triangulasi metode dilakukan dengan cara membandingkan informasi atau data dengan cara yang berbeda. Untuk memperoleh kebenaran informasi yang handal dan gambaran yang utuh mengenai informasi tertentu, peneliti bisa menggunakan metode wawancara dan obervasi atau pengamatan untuk mengecek kebenarannya. Selain itu, peneliti juga bisa menggunakan informan yang berbeda untuk mengecek kebenaran informasi tersebut. Triangulasi tahap ini dilakukan jika data atau informasi yang diperoleh dari subjek atau informan penelitian diragukan kebenarannya. Hasil penelitian ini Pengajuan kepailitan pada Pengadilan Niaga yang melibatkan hakim pengawas dan kurator. Dalam menentukan keabsahan utang piutang oleh seorang hakim pengawas digunakan ilmu akuntansi forensik dan akuntansi kerugian, dengan kurator yang bertugas untuk membagikan budel (harta) pailit kepada para kreditur dengan urutan pembagian harta bagi kreditor separatis (kreditor yang memiliki jaminan), kreditor preferen dan kreditor kongruen (kreditur yang tidak memiliki jaminan). Pada umunya tindakan fraud yang dilakukan debitur adalah dengan menyembunyikan aset dan penjualan sedangkan tindakan fraud yang dilakukan dengan motif untuk memperoleh budel (harta) pailit.
\end{abstract}

Kata Kunci : Akuntansi kerugian, Kurator, Tindakan Fraud, Budel (harta) Pailit.

\begin{abstract}
The purpose of this study is to interpret the construction of accounting losses in disclosing fraud and the bankruptcy practices of client financial statements. The research method used is a qualitative method - the interpretive paradigm with a phenomenal approach with method triangulation is done by comparing information or data in different ways. To obtain the truth of reliable information and a complete picture of certain information, researchers can use interview and observation or observation methods to check the truth. In addition, researchers can also use different informants to check the correctness of the information. Triangulation of this stage is done if the data or information obtained from the subject or research informants is doubtful. The results of this study were filing bankruptcy at the Commercial Court involving a supervisory judge and curator. In determining the validity of accounts payable by a supervisory judge used the science of forensic accounting and loss accounting, with the curator in charge of distributing bankruptcy (assets) to creditors in the order of division of property for separatist creditors, Preferred creditors and congruent creditors (creditors who have no collateral). In general, fraud actions carried out by debtors are by hiding assets and sales while fraud is carried out with the motive to obtain bankruptcy (assets).
\end{abstract}

Keywords: Forensic Accounting, Curators, fraud actions,Budel (assets) bankruptcy. 


\section{PENDAHULUAN}

Pengambilalihan jaminan oleh lebih dari satu kreditor dari debitur pada perusahaan yang mengalami kepailitan dapat menimbulkan berbagai perselisihan. Oleh sebab itu maka Pemerintah membentuk Pengadilan Niaga yang digunakan sebagai sarana dalam penyelesaian perselisihan tersebut. Berdasarkan sumber dari Pengadilan Niaga Jakarta Pusat, jumlah pengajuan kepailitan di Pengadilan Niaga dari tahun 2012 sebanyak 9 perkara yang berasal dari perkara tahun sebelumnya dan 76 perkara yang masuk tahun 2012, dimana 64 perkara telah diputuskan status kepailitan dan gagal pailit, 10 perkara dicabut selama tahun berjalan dan sebanyak 11 perkara belum diselenggarakannya persidangan. Sejumlah perkara yang telah diputuskan pada tahun 2012 ternyata belum memberikan kepuasan bagi termohon sehingga terdapat 47 perkara yang melakukan kasasi dan 19 perkara dilakukan peninjauan kembali.

Kasus-kasus yang dialami profesi akuntan publik (auditor), secara implisit mempunyai dampak terhadap perkembangan profesi auditor di masa mendatang. Auditor dianggap telah bertindak menyimpang dari aturan yang telah ada dan tidak beretika seperti yang telah disyaratkan dalam standar profesional akuntan. Salah satu profesi dari akuntan yang paling menonjol adalah akuntan publik terutama karena kegiatan audit (pemeriksaan) atas laporan keuangan yang dibuat manajemen (Nimastuti, 2005). Melalui pemberian jasa audit, akuntan publik dapat membantu manajemen maupun pihak luar sebagai pemakai laporan keuangan untuk menentukan secara obyektif dapat dipercaya atau tidaknya laporan keuangan suatu perusahaan. Namun demikian, dalam praktiknya tidak sedikit pelanggaran terhadap etika profesi dilakukan. Dari tinjauan historis yang ada membuktikan adanya berbagai kasus perdata dan pidana di Amerika Serikat sejak periode 1970-an diantaranya kasus Penn Central (1972), Equity Funding (1974), Kllearn Properties (1977), adalah serentetan kasus yang menggambarkan beragam tindakan penyelewengan dan kecurangan profesi audit (Laela, 1997). Sorotan lebih tajam adalah setelah terungkapnya skandal akuntansi yang dilakukan perusahaan energi Enron.

Menurut Satyo (2005), skandal keuangan Enron yang melibatkan salah satu dari lima kantor akuntan terbesar di dunia (the big five accounting firm) yaitu Arthur Andersen, diikuti dengan mencuatnya beberapa kasus skandal lainnya, seperti kasus dalam pengajuan kepailitan di Pengadilan Niaga, tidak semua termohon mendapatkan keputusan pailit, namun ada juga yang mendapat putusan gagal pailit. Contoh kasus perusahaan yang gagal pailit adalah PT Dirgantara Indonesia yang dinyatakan pailit oleh Pengadilan Niaga Jakarta Pusat pada 4 September 2007, kemudian keputusan pailit tersebut dibatalkan oleh Mahkamah Agung pada 24 Oktober 2007. Kasus lainnya adalah Mahkamah Agung mengabulkan kasasi PT Telekomunikasi Seluler atas putusan pailit Pengadilan Niaga Jakarta Pusat dari gugatan PT Prima Jaya Informatika. Perkara dengan nomor 704 K/Pdt.Sus/2012 ini diputuskan pada Rabu, 21 November 2012, oleh Majelis Hakim Kasasi.

Menurut Rachmadi Usman (2004: 12) kepailitan adalah keadaan dimana seorang debitur tidak mampu melunasi utang-utangnya pada saat utang tersebut jatuh tempo. Kasus kepailitan yang paling menyita perhatian adalah suatu BUMN yaitu PT Dirgantara Indonesia yang dinyatakan pailit oleh Pengadilan Niaga Jakarta Pusat pada 4 September 2007, walaupun keputusan pailit tersebut dibatalkan oleh Mahkamah Agung pada 24 Oktober 2007. Contoh kasus lainnya adalah kepailitan yang dialami PT Metro Batavia (Batavia Air) dikarenakan utang yang jatuh tempo tidak kunjung dibayar sebesar US\$4,68 juta. Gugatan pailit ini diajukan oleh International Lease Finance Corporation (ILFC). Keputusan pailit PT Metro Batavia (Batavia Air) dikeluarkan oleh Pengadilan Niaga Jakarta Pusat dalam putusannya No.77/pailit/2012/PN.NIAGA.JKT. PST pada tanggal 30 Januari 2013. (Maria Yuniar, 2013).

Adrian Sutedi (2009: 26) menyebutkan ada beberapa faktor perlunya pengaturan mengenai kepailitan dan penundaan kewajiban pembayaran utang, yakni pertama, untuk menghindari perebutan harta debitur apabila dalam waktu yang sama ada beberapa kreditor yang menagih piutangnya. Kedua, untuk menghindari adanya kreditor pemegang hak jaminan kebendaan yang menuntut haknya dengan cara menjual barang milik debitur tanpa memerhatikan kepentingan debitur atau para kreditor lainnya. Ketiga, untuk menghindari adanya kecurangan-kecurangan yang dilakukan oleh salah seorang kreditor atau debitur sendiri. Misalnya, debitur berusaha untuk memberi keuntungan kepada seorang atau beberapa orang kreditor tertentu sehingga kreditor lainnya dirugikan, atau adanya perbuatan curang dari debitur untuk melarikan semua harta kekayaannya dengan maksud untuk melepaskan tanggung jawabnya terhadap para kreditor.

Perkara kepailitan di Indonesia cukup banyak setiap tahunnya yang masuk ke Pengadilan Niaga. 
Hal tersebut dapat dilihat dari jumlah perkara yang masuk ke Pengadilan Niaga Jakarta Pusat. Daftar Perkara Kepailitan Tahun 2010-2012 Penyelesaian masalah kepailitan dapat ditempuh melalui pembicaraan antara debitur dan kreditor melalui mediasi maupun ditempuh dengan jalur hukum dengan mengajukan ke pengadilan niaga. Berdasarkan data yang diperoleh dari Pengadilan Niaga Jakarta Pusat, perkara kepailitan yang masuk dari tahun ke tahun mengalami fluktuasi tetapi tidak terlalu signifikan. Pada tahun 2010 terdapat 86 perkara yang masuk. Pada tahun 2011 lebih banyak 1 perkara menjadi 87 perkara yang masuk. Pada tahun 2012 mengalami penurunan menjadi 76 perkara yang masuk. Hal ini menunjukkan bahwa minat penyelesaian masalah kepailitan di pengadilan negeri masih tetap tinggi. Di Indonesia hukum yang mengatur tentang hal tersebut adalah UndangUndang No. 37 Tahun 2004 Tentang Kepailitan dan Penundaan Kewajiban Pembayaran Utang. Pada awalnya pengadilan niaga hanya beroperasi pada Pengadilan Negeri Jakarta Pusat, namun setelah dikeluarkannya Keputusan Presiden No. 97 Tahun 1999, pemerintah membentuk pengadilan niaga pada empat wilayah pengadilan negeri lainnya, yaitu di Pengadilan Negeri Makassar, Pengadilan Negeri Medan, Pengadilan Negeri Surabaya, dan Pengadilan Negeri Semarang.

Permohonan kepailitan suatu perusahaan menurut Adrian Sutedi (2009: 39) dapat dilakukan oleh beberapa pihak. Pertama, pihak debitur sebagai pemohon kepailitan. Seorang debitur dapat mengajukan permohonan kepailitan apabila mempunyai dua atau lebih kreditor (lebih dari satu kreditor) dan debitur sedikitnya tidak membayar satu utang yang telah jatuh waktu dan telah dapat ditagih. Namun, ketentuan tersebut membuka kemungkinan bagi debitur yang nakal untuk melakukan rekayasa demi kepentingannya. Kedua, pihak kreditor sebagai pemohon kepailitan. Kreditor dapat mengajukan permohonan kepailitan apabila debitur mempunyai dua atau lebih kreditor dan sedikitnya tidak membayar satu utang yang telah jatuh tempo dan dapat ditagih. Ketiga, pihak kejaksaan sebagai pemohon kepailitan. Menurut pasal 2 ayat (2) Undang-Undang No. 37 Tahun 2004 menentukan bahwa permohonan pernyataan pailit dapat diajukan oleh kejaksaan untuk kepentingan umum. Dimana tata cara permohonan kepailitan sama dengan permohonan yang diajukan oleh debitur dan kreditor. Pada dasarnya kepailitan dapat diajukan oleh semua jenis kreditor. Tidak ada batasan mengenai kualifikasi kreditor yang dapat mengajukannya. Sepanjang kreditor tersebut dapat membuktikan secara sederhana bahwa ada lebih dari satu utang dan salah satunya telah jatuh tempo, maka secara formal, hakim wajib menyatakan debitur pailit. Pihak-pihak yang terlibat di Pengadilan Niaga terdiri dari debitur, kreditor, hakim, jaksa, dan kurator.

Kepailitan dapat terjadi ketika aset yang dimiliki oleh perusahaan lebih kecil daripada utang yang harus dibayarkan kepada para kreditor. Oleh karena itu kemungkinan adanya perselisihan antara kreditor dengan kreditor lainnya dalam mengakui aset yang seharusnya diterima oleh masing-masing kreditor. Selain itu kepailitan juga dapat terjadi ketika aset yang dimiliki oleh perusahaan lebih besar daripada utang yang harus dibayarkan kepada para kreditor. Sehingga kemungkinan terjadi perselisihan antara debitur dan para kreditor dalam pembagian aset, karena dalam situasi seperti ini debitur masih memiliki hak terhadap kelebihan aset setelah dibayarkan utang kepada para kreditor.

Kurator adalah orang yang mengurusi kegiatan debitur setelah pernyataan pailit. Pengangkatan kurator yang akan membereskan dan mengurus harta debitur dilakukan oleh pengadilan. Seseorang yang dapat menjadi kurator adalah sarjana hukum atau sarjana ekonomi jurusan akuntansi. Dalam menjalankan tugasnya untuk menghitung aset debitur, seorang kurator menggunakan keahlian khusus yang disebut akuntansi forensik. Akuntansi forensik adalah praktik khusus bidang akuntansi yang menggambarkan keterlibatan yang dihasilkan dari perselisihan aktual atau yang diantisipasi atau ligitasi.

Pengaturan dalam pengajuan kepailitan dan penundaan kewajiban pembayaran utang diperlukan karena pertama, untuk menghindari perebutan harta debitur apabila dalam waktu yang sama ada beberapa kreditor yang menagih piutangnya. Kedua, untuk menghindari adanya kreditor pemegang hak jaminan kebendaan yang menuntut haknya dengan cara menjual barang milik debitur tanpa memerhatikan kepentingan debitur atau para kreditor lainnya. Ketiga, untuk menghindari adanya kecurangan-kecurangan yang dilakukan oleh salah seorang kreditor atau debitur sendiri. Misalnya, debitur berusaha untuk memberi keuntungan kepada seorang atau beberapa orang kreditor tertentu sehingga kreditor lainnya dirugikan, atau adanya perbuatan curang dari debitur untuk melarikan semua harta kekayaannya dengan maksud untuk melepaskan tanggung jawabnya terhadap para kreditor.

Keterkaitan antara tindakan kecurangan dalam kepailitan (fraud in Bankrupcy and Divorce) dibagi menjadi 3 (tiga) pertama yaitu fraud yang 
menyebabkan terjadinya bankrupt, kedua bankrupt digunakan untuk melakukan fraud, dan ketiga bankrupt digunakan untuk menyembunyikan fraud. Berdasarkan hal tersebut, potensi terjadinya fraud dapat terjadi dalam proses kepailitan, seperti yang diungkapkan bahwa perusahaan yang bankrupt cenderung untuk melakukan manipulasi laporan keuangan. Penelitian tersebut mencoba untuk menguatkan artikel yang dikeluarkan oleh Delloite yang menyatakan bahwa perusahaan yang berpotensi mengalami bankrupt tiga kali lebih mungkin melakukan fraud dibandingkan perusahaan yang tidak mengalami bankrupt.

Dalam menjalankan usahanya, suatu perusahaan tidak selalu mengalami kesuksesan. Terkadang suatu perusahaan berada pada keadaan dimana mempunyai banyak utang dan tidak dapat melanjutkan usahanya atau biasa disebut dengan bankrupt atau pailit. Kepailitan sebagai ketidakmampuan pihak pengutang (debitur) untuk memenuhi kewajibannya kepada pihak pemberi utang (kreditor) tepat pada waktu yang sudah ditentukan. Syarat-syarat suatu perusahaan dapat dipailitkan adalah: 1) adanya utang, 2) minimal satu utang sudah jatuh tempo dan dapat ditagih, 3) adanya debitur, 4) minimal ada dua kreditor, 5) permohonan pernyataan pailit, 6) pernyataan pailit oleh Pengadilan Niaga. Apabila perusahaan telah dinyatakan pailit, maka kegiatan perusahaan tersebut diambil alih oleh kurator untuk mengurus dan membereskan harta pailit.

Pada saat yang bersamaan perusahaan tidak dapat membayar utang kepada para kreditor tersebut, hal itu dapat memicu adanya perselisihan antar kreditor dalam hal pembayaran utang. Jika hal ini terjadi, maka perselisihan itu dapat diselesaikan melalui Pengadilan Niaga, ataupun melalui cara di luar pengadilan, contohnya mediasi, arbitrase, konsiliasi, dan negosiasi. Dalam Pengadilan Niaga, status kepailitan tidak selalu diajukan oleh kreditor, tetapi debitur pun dapat memohon kepada pengadilan untuk mendapatkan keputusan kepailitan. Pada proses penyelesaian kepailitan dalam Pengadilan Niaga terdapat beberapa pihak yang terlibat, diantaranya jaksa, kreditor, debitur, dan kurator. Kurator menurut Adrian Sutedi (2009: 60) adalah orang yang mengurus kegiatan debitur setelah adanya pernyataan pailit dari penngadilan. Sesuai dengan Pasal 69 Undang-Undang Kepailitan, kurator mempunyai tugas melakukan pengurusan dan/ atau pemberesan harta pailit. Dalam menyelesaikan tugasnya, kurator harus memiliki keahlian di bidang akuntansi, hukum, dan audit atau biasa disebut dengan akuntansi forensik.
Penelitian Imang DP, I. Ghozali and T.Achmad (2017) Sistem Whistleblowing berpengaruh Positif pada pencegahan kecurangan (fraud) pelaporan keuangan. Jumansyah, dkk. (2011) menyatakan bahwa akuntansi forensik dapat membantu menyelesaikan kasus-kasus hukum dengan cara membantu para penegak hukum untuk melakukan perhitungan dan pengungkap pos kecurangan, mendeteksi penyebab terjadinya kecurangan, menemukan petunjuk awal (indiciaof fraud) terjadinya kecurangan, dan mendeteksi kira-kira waktu kecurangan dapat terungkap dan membedakan kecurangan yang terungkap melalui tip atau secara kebetulan. Menurut Wells (2007), kecurangan akuntansi (fraud) mengacu kepada kesalahan akuntansi yang dilakukan secara sengaja dengan tujuan menyesatkan pembaca/pengguna laporan keuangan.

Kecurangan akuntansi merupakan suatu tindakan ilegal yang sangat erat hubungannya dengan etika. Penelitian dari Puspasari dan Suwardi (2012), menemukan bahwa etika dan lingkungan pengendalian akuntansi merupakan dua hal yang sangat penting terkait kecenderungan seseorang dalam melakukan kecurangan akuntansi. Selain faktor rasionalisasi yang berkaitan erat dengan etika, faktor lain yang menjadi penyebab kecurangan akuntansi adalah faktor kesempatan. Salah satu penyebab adanya kesempatan untuk melakukan kecurangan akuntansi adalah kurangnya pengawasan dan lemahnya pengendalian internal organisasi. Coram et al. (2008) menjelaskan bahwa organisasi yang memiliki fungsi internal audit akan lebih dapat mendeteksi kecurangan akuntansi. Penelitian Hogan et al. (2008) menemukan bahwa auditor berperan dalam mengurangi faktor kesempatan (opportunity) dalam kecurangan akuntansi.

Motivasi penulis untuk menulis artikel tentang kepailitan ini mengenai konstruksi akuntansi kerugian dalam mengungkap fraud pada proses kepailitan belum banyak dilakukan di Indonesia, penulis-penulis sebelumnya lebih banyak memfokuskan pada tindakan fraud saja yang tidak dikaitkan dengan proses kepailitan yang diajukan di Pengadilan Niaga.

Berdasarkan hal tersebut maka dilakukan penelitian untuk: 1) mengetahui penggunaan akuntansi kerugian dalam mengungkap fraud pada proses kepailitan dan 2) mengetahui potensi tindakan fraud pada perusahaan yang mengalami kepailitan. Adapun tujuan penelitian ini untuk mengetahui dan menganalisis konsruksi akuntansi forensik terhadap kepailitan dan dapat mendeteksi adanya kecurangan 
(fraud) laporan keuangan klien.

\section{KAJIAN TEORI}

\section{Institutional Theory}

Institutional theory atau teori kelembagaan adalah teori yang menjelaskan tentang bagaimana suatu perusahaan berkembang dan bertahan ketika berada dalam lingkungan yang kompetitif yang penuh dengan para pesaing, serta mempelajari bagaimana cara perusahaan untuk memuaskan stakeholder (Rinaldi, 2009). Teori ini juga menyebutkan bahwa suatu struktur dalam organisasi dan perilaku individu di dalamnya dipengaruhi oleh budaya, politik, dan tekanan yang terjadi di perusahaan (Fogarty, 1996 dalam Chariri 2006). Lawrence (2008) menyatakan bahwa institutional theory dapat digunakan untuk menganalisis suatu fenomena sosial sesuai dengan peraturan yang mengikat, praktik, dan struktur yang mengatur suatu kondisi dan tindakan. Sedangkan menurut Scott (2004), teori ini mengikuti suatu struktur sosial yang lebih mendalam dan kompleks. Institutional theory mempertimbangkan prosesproses yang mana struktur, yang menyangkut skema, peraturan, norma, dan kebiasaan ditetapkan sebagai pedoman bagi perilaku sosial (Scott, 2004). Pada prisipnya terdapat dua asumsi dasar yang melekat dalam pengertian teori ini. Hal ini disampaikan oleh Scott (1987); Selznick (1957) dalam Chariri (2006). Pertama, suatu institusi didasarkan pada suatu keyakinan bahwa lingkungan dalam suatu organisasi dapat membentuk perilaku setiap individu yang terlibat di dalamnya dan sebaliknya organisasi tersebut juga dapat dibentuk oleh tidakan individu yang terlibat dalam lingkungan organisasi yang bersangkutan. Kedua, institusi melihat suatu organisasi sebagai sistem yang terbuka. Artinya, bahwa dalam lingkungan eksternal dan pelaku dalam organisasi memainkan peranan dalam membentuk struktur dan kegiatan institusi (Chariri, 2006). Suatu organisasi adalah bagian dari masyarakat sosial, oleh karena itu organisasi tidak dapat bertahan untuk hidup sendiri.

\section{Teori Konstruksi sosial}

Teori konstruksi sosial pertama dikemukakan oleh oleh Berger dan Luckman (1966) yang menerbitkan buku berjudul The Social Construction of Reality. Konstruksi sosial merupakan teori yang dapat digunakan untuk menerangkan tentang dinamika sosial (Chariri, 2006). Tatanan sosial merupakan produk manusia (Berger dan Luckman, 1966) yang mempelajari hubungan antara pemikiran manusia dan konteks sosial di mana pemikiran itu timbul, berkembang, dan dilembagakan. Fokus karya Berger adalah hubungan antara masyarakat dan individu. Berger mengembangkan teori sosiologis yang menyatakan bahwa masyarakat sebagai realitas objektif dan realitas subjektif. Analisis mengenai msyarakat sebagai realitas subjektif menyatakan bagaimana realitas telah menghasilkan dan terus menghasilkan individu. Berger membuat Konsepkonsep atau penemuan-penemuan baru manusia manjadi bagian dari realitas masyarakat yang disebut dengan reifikasi (Sriningsih dalam Suyanto, 2010). Berger dan Luckman (1990) mendefinisikan teori ini sebagai "kenyataan” dan "pengetahuan” dalam konteks sosial.

Kenyataan sosial seperti ini dapat ditemukan dalam pengalaman intersubjektif (Sriningsih dalam Suyanto, 2010). Konsep intersubjektif merujuk pada dimensi struktur kesadaran umum ke kesadaran individual dalam suatu kelompok yang saling berinteraksi. Melalui intersubjektivitas dapat dijelaskan bagaimana kehidupan masyarakat dibentuk secara terus-menerus. Masyarakat adalah buatan kultural dari masyarakat tertentu, selain itu manusia juga pencipta dunianya sendiri meliputi lingkungan fisik, organisasi sosial, dan sistem nilainya (Sriningsih dalam Suyanto, 2010). Berger dan Luckman (1966) memandang m lektis yang simultan, yaitu pertama externalization, objectivation, dan internalization. Externalization menunjukkan bahwa suatu realita sosial dapat terbentuk melalui tidakan individu yang diwujudkan melalui suatu interaksi sosial. Untuk realisasinya, di dalam interaksi sosial ini individuindividu membuat suatu simbol dan benda-benda hasil buatannya.

\section{Akuntansi Forensik}

Definisi akuntansi forensik menurut Hopwood et al (2008 : 3) yaitu "forensic accounting is the application of investigative and analytical skills for the purpose of resolving financial issues in a manner that meets standards required by courts of law." Akuntansi forensik adalah aplikasi keterampilan investigasi dan analitik yang bertujuan untuk menyelesaikan masalah-masalah keuangan melalui cara-cara yang sesuai dengan standar yang ditetapkan oleh pengadilan dan hukum. Menurut Tuanakotta (2010 : 4) akuntansi forensik ialah "penerapan disiplin akuntansi dalam arti luas, termasuk auditing, pada masalah hukum untuk 
penyelesaian hukum di dalam atau di luar pengadilan”. Menurut Bologna dan Lindquist yang dikutip dalam Crumbley dan Apostolou (2002 : 17) mendefenisikan akuntansi forensik sebagai "forensic and investigative accounting is the application of financial skills and an investigative mentality to unresolved issues, conducted within the context of the rules of evidence". Dengan terjemahan sebagai berikut, akuntansi forensik dan investigasi adalah aplikasi kecakapan finansial dan sebuah mentalitas penyelidikan terhadap isu-isu yang tak terpecahkan, yang dijalankan dalam konteks rules of evidence”. Menurut de Lorenzo (1993 : 23) mendefenisikan akuntansi forensik "forensic accounting could be described as the application of accounting knowledge and skills to legal problems, though in today's complex commercial environment the meaning and use of the term is much broader". Dengan terjemahan sebagai berikut, penerapan pengetahuan akuntansi dan keterampilan untuk masalah hukum, meskipun dalam kompleks lingkungan komersial dan penggunaan istilah tersebut jauh lebih luas.

\section{Mengapa Akuntansi Forensik?}

Tingkat korupsi yang tinggi menjadi pendorong yang kuat untuk berkembangnya praktik akuntansi forensik di Indonesia. Akuntansi forensik diperlukan karena adanya potensi fraud yang mampu menghancurkan pemerintahan, bisnis, pendidikan, departemen maupun sektor-sektor lainnya. Menurut Tuanakotta yang dikutip dalam Asia Pacific Fraud Convention (2007 : 23) "pada pertemuan Asia Pacific mengenai fraud tahun 2004, Deloitte Touche Tohmatsu melakukan polling terhadap 125 delegasi”. Polling tersebut menunjukkan bahwa kebanyakan peserta (82\%) menyatakan bahwa mereka mengalami peningkatan dalam corporate fraud (fraud di perusahaan) dibandingkan dengan tahun sebelumnya; 36\% di antaranya menyatakan peningkatan fraud yang teramat besar. Berdasarkan forecast BMI kuartal keempat 2005 memuat SWOT Analysis mengenai lingkungan usaha diperoleh bahwa dalam kategori Weakness, BMI memasukkan sistem hukum di Indonesia yang tidak handal sedangkan dalam kategori Opportunities disebutkan bahwa pembasmian korupsi akan meningkatkan minat para investor untuk menanamkan uang mereka di Indonesia. Fraud terjadi karena corporate governance yang rendah, lemahnya enforcement, kelemahan dalam bidang penegakan hukum, standar akuntansi dan lain-lain konsisten dengan tingkat korupsi dan kelemahan dalam penyelenggaraan negara.

Profesi akuntan forensik sangat dibutuhkan oleh penegak hukum, yakni jika ada sebuah transaksi yang dicurigai, maka abdi hukum bisa meminta bantuan akuntan forensik untuk menjelaskan dari mana dan ke mana transaksi tersebut mengalir. Akuntan forensik menerapkan keterampilan khusus di bidang akuntansi, audit, keuangan, metode kuantitatif, beberapa bidang hukum, penelitian dan keterampilan dalam menginvestigasi untuk mengumpulkan, menganalisis, dan mengevaluasi bukti dan untuk menginterpretasikan dan mengkomunikasikan temuan. Seorang akuntan forensik membantu organisasi atau individu terutama untuk memberikan dukungan manajemen dalam bentuk laporan untuk mendeteksi fraud dan dukungan litigasi, terutama melalui kesaksian saksi ahli.

\section{Kerangka Konseptual}

Semakin pesatnya perkembangan akuntansi forensik dapat mencetuskan ide baru bagi pelaku fraud untuk melakukan tindakan penipuan melalui praktik laporan keuangan yang sering disebut sebagai Fraud in financial Statement. Dalam penelitian yang dilakukan oleh Pearson dan Singleton (2008) menerapkan kepada mahasiswa atau mahasiswi lulusan akuntansi harus mampu menguasai ilmu akuntansi kerugian untuk mendukung upaya anti penipuan dan dapat melakukan akuntansi forensik dan audit investigasi. Baik mahasiswa akuntansi ataupun auditor perlu akrab dengan peran akuntansi forensik dan bermain di lingkungan akutansi. Bisnis juga telah tumbuh dalam penggunaan praktik kepailitan dan ketergantungan pada akuntansi forensik. Ketergantungan terhadap akuntansi dalam suatu organisasi akan meningkatkan kerugian akibat penipuan dan penyalahgunaan (fraud). Kerangka pemikiran yang telah diuraikan oleh penulis di atas dapat dilihat pada gambar kerangka konseptual, berikut ini:

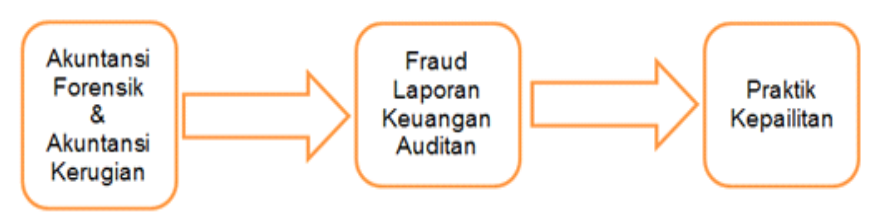




\section{METODE}

Penelitian ini menggunakan menggunakan metode penelitian kualitatif dengan paradigma interpretif pendekatan fenomenologis merupakan tradisi penelitian kualitatif yang berakar pada filosofi dan psikologi, dan berfokus pada pengalaman hidup manusia (sosiologi).

Pendekatan fenomenologi hampir serupa dengan pendekatan hermeneutics yang menggunakan pengalaman hidup sebagai alat untuk memahami secara lebih baik tentang sosial budaya, politik atau konteks sejarah dimana pengalaman itu terjadi. Triangulasi metode dilakukan dengan cara membandingkan informasi atau data dengan cara yang berbeda, seperti; metode wawancara, obervasi, dan survei.

Untuk memperoleh kebenaran informasi yang handal dan gambaran yang utuh mengenai informasi tertentu, peneliti bisa menggunakan metode wawancara dan obervasi atau pengamatan untuk mengecek kebenarannya. Selain itu, peneliti juga bisa menggunakan informan yang berbeda untuk mengecek kebenaran informasi tersebut. Triangulasi tahap ini dilakukan jika data atau informasi yang diperoleh dari subjek atau informan penelitian diragukan kebenarannya.

Dalam kegiatan penelitian lapangan seseorang akan begitu cepat kehilangan pandangannya tentang berapa banyak data, data macam apa, yang telah dikumpulkan dari informan yang berbeda-beda. Karena data ini seringkali koroboratif -dengan memverifikasi penjelasan yang diberikan orang lain, menguji tesis yang muncul - ketidakhadirannya lebih serius daripada sekedar "kehilangan data". Keseluruhan data adalah landasan bukti tempat berdirinya bangunan yang harus disusun peneliti menuju kesimpulan.

Salah satu instrument yang dibuat untuk memudahkan dalam rangka triangulasi data adalah lembar catatan data. Lembar catatan data dapat membantu peneliti dalam mengorganisir data, membuat ringkasan sementara dari permasalahan penelitian yang terkait sekaligus mengcrosscheck data apasaja yang telah tersedia dan belum serta data apa saja yang layak analisis atau yang telah dikonfirm dengan sumber data lain.

\section{HASIL DAN PEMBAHASAN}

\section{Konstruksi Akuntansi Kerugian dalam Praktek Kepailitan}

Pengajuan tindakan kepailitan dapat dilakukan dengan syarat apabila terdapat utang kepada dua atau lebih kreditor yang telah jatuh tempo akan tetapi tidak dapat dilunasi oleh debitur, dimana debitur harus dalam keadaan insolvent, yaitu tidak membayar lebih dari 50\% utang-utangnya. Pengajuan proses kepailitan dapat diajukan oleh 3 (tiga) pihak yaitu kepailitan yang diajukan oleh debitur, kepailitan yang diajukan oleh kreditor dan kepailitan yang diajukan oleh lain-lain.

Pelaksanaan proses kepailitan dilakukan di Pengadilan Niaga, dimana hakim pengadilan akan menunjuk hakim pengawas dan kurator. Hakim pengawas akan memutuskan suatu debitur dinyatakan pailit atau gagal pailit tidak lebih dari 60 hari setelah pengajuan kepailitan. Pada saat dipersidangan maka hakim pengawas memerlukan bukti dari para kreditur dan debitur atas utang piutang yang ada.

Berdasarkan hasil observasi di persidangan niaga seorang hakim pengawas melakukan pencocokan dengan bukti berupa perjanjian utang piutang dan memperoleh keterangan baik dari pemohon dan termohon atau kreditor dan debitur. Ilmu akuntansi forensik berperan dalam proses tersebut untuk menentukan keabsahan dari bukti berupa dokumen utang piutang dan bukti lainnya yang memperkuat putusan oleh seorang hakim pengawas. Setelah suatu perusahaan dinyatakan pailit maka akan ada kurator yang akan melakukan pemberesan. Maksudnya pemberesan di sini adalah suatu keadaan dimana kurator melakukan pembayaran kepada para kreditor dari hasil penjualan harta pailit. Seperti yang diungkapkan oleh informan 1 yang berprofesi sebagai kurator : "Jadi syarat utama pailit itu adalah adanya dua kreditor utang yang tidak bisa dibayar.,kalau terdapat 2 kreditor yang utangnya sudah jatuh tempo akan tetapitidak bisa dibayar itu bisa dijatuhi pailit.Pengajuan kepailitian bisa oleh debitur atau kreditur, tapi kebanyakan oleh kreditur. Debitur itu biasanya kalo dia udah merasa tidak sanggup membayar utangnya dia, takutnya dia ada apa-apa suatu saat kedepannya, dia bisa mengajukan pailit. Pekerjaan kurator itu cuma satu, yaitu kalau ada yang pailit baik perusahaan maupun perorangan dalam hukum maka itu tugas kurator yang mengurus segala harta kekayaannya, maksudnya disini, kalau misal perusahaan atau orang bankrupt dimana utang banyak, takutnya tidak ada keseimbangan jadi misalnya begini seseorang punya utang kepada A,B, dan C, ketika dia tidak bisa membayar kepada ketiganya dan dinyatakan pailit, kemudian hanya si A dan B kebagian atas harta pailit sedangkan C tidak kebagian berarti tidak ada keseimbangan,maka tugas kurator yang mengurus semuanya”.

Seorang kurator juga dapat memiliki wewenang 
untuk menjalankan usaha suatu perusahaan yang dinyatakan pailit. Seperti yang diungkapkan informan 1 : "Jadi setelah adanya keputusan pailit, maka pada jam 00.00 semuanya dikuasai oleh kurator, baik asetnya, perusahaannya. Tanpa izin kurator tidak bisa, hakim pengawas juga tidak boleh. Jika perusahaan A dinyatakan pailit kemudian jam 00.00 maka kurator akan bergerak, biasa kurator minta cash flow perusahaan gimana, merugi atau untung. Jadi kalau masih untung kurator punya hak untuk menjalankan perusahaannya. Yang penting ada keuntungan untuk budel pailit. Kita kan ngejarnya budel pailit. Selama masih ada budel pailit semua bisa dikerjakan. Misalnya toko buah, buah kan cepat busuk, daripada kita tahan mending kita jual saja. Daripada busuk kita rugi, mending kita jual Rp 200 misalnya. Dimana budel pailit bisa besar.Jika perusahaan memiliki sewa kontrak, apabila kontrak ini kita teruskan kita merugi maka kurator akan hentikan”.

Dalam proses pembagian budel (harta) pailit maka seorang kurator harus melakukan investigatif untuk mengetahui status kreditor apakah kreditor tersebut merupakan separatis, preferen dan atau kongruen. Seperti yang diungkapkan informan 1 : "Jika perusahaan dinyatakan pailit maka kurator melalui aturan dan perundang-undangan akan memastikan bahwa kreditur tertentu masuk sebagai separatis, preferen atau kongruen. Kalau separatis dia punya hak untuk menjual. Misalnya perusahaan (debitur) menjaminkan rumahnya ke Bank, selama proses pailit bank diberi waktu selama 90/ 60 hari untuk menjual sendiri untuk melunasi utang, apabila dia tidak bisa menjual kembalikan ke pailit, kurator yang menjual. Kreditur preferen itu adalah yang haknya didahulukan seperti hutang pajak kepada Negara dan kreditur kongruen adalah kreditur yang tidak memiliki jaminan. Tidak sembarang orang boleh menagih kepada perusahaan yang dinyatakan pailit, semua itu harus melalui kurator”.

Hal ini sesuai dengan pernyataan bahwa tugas kurator dalam administratif yaitu melakukan pengumuman (pasal 15 ayat (4)), mengundang rapat kreditor, menangani harta kekayaan debitur pailit, melakukan pencatatan atau inventarisasi harta pailit (Pasal 100 sampai dengan Pasal 103 UndangUndang Kepailitan) serta membuat laporan rutin kepada hakim pengawas selama 3 (tiga) bulan sekali. (Pasal 74 Undang-Undang Kepailitan).Tugas kurator dalam mengurus atau mengelola harta pailit, selama proses kepailitan belum sampai pada keadaan insolvensi (pailit), maka kuartor dapat melanjutkan pengelolaan usaha-usaha debitur pailit sebagaimana layaknya organ perseroan (direksi) atas izin rapat kreditor. (Pasal 104 ayat (1) Undang-Undang Kepailitan). Pengelolaan hanya dapat dilakukan apabila debitur pailit masih memiliki suatu usaha yang masih berjalan.

Syarat seseorang dapat menjadi kurator adalah diharuskan untuk mengikuti pendidikan profesi, kurator merupakan sarjana hukum atau sarjana eknomi jurusan atau program studi akuntansi. Akan tetapi di Indonesia kebanyakan kurator berlatar belakang pendidikan hukum dan hanya sedikit yang berlatarbelakang pendidikan akuntansi. Sehingga dalam proses kepailitan ini, maka seorang kurator yang berlatarbelakang pendidikan hukum akan meminta jasa akuntansi forensik atau audit investigatif kepada kantor akuntan publik agar dapat menghitung budel (harta) pailit. Seperti yang diungkapkan informan 1 : "Untuk masalah akuntansi, kurator yang berlatarbelakang pendidikan hukum tentuknya akan sulit memahami masalah penghitungan laporan keuangan perusahaan, sehingga kebanyakan kurator tersebut termasuk saya menyewa jasa akuntan publik. Kalau akuntan kan minimal dia tau cash flow perusahaan, cuma mungkin kalau dia ada masalah hukum baru dia sewa lawyer. Mayoritas kurator lulusan hukum”.

Informan 2 yang merupakan auditor senior mengungkapkan bahwa kadangkala kurator tidak memiliki pemahaman yang cukup dalam akuntansi dan audit investigatif sehingga membutuhkan jasa kantor akuntan publik, seperti yang dikutip dari pernyataan informan 2 : "Kurator kadangkala tidak memahami secara keseluruhan tentang laporan keuangan dan audit investigatifsehingga membutuhkan jasa akuntan public untuk penelusuran eksistensi atas asset dan kewajiban yang tercantum dalam laporan keuangan perusahaan”. Proses kepailitan menggabungkan 3 (tiga) fokus keilmuan didalamnya yaitu akuntansi, audit dan hukum. Sehingga dalam praktek kepailitinan ini seorang hakim pengawas dan kurator menggunakan ilmu akuntansi forensik dalam menyatakan pailit dan membagikan budel (harta) pailit kepada para debitur.

\section{Potensi Fraud Dalam Kepailitan/Bankruptcy Fraud yang Menyebabkan Terjadinya Kepailitan/Bankruptcy}

Dalam proses kepailitan dapat diajukan oleh 3 (tiga) pihak yaitu debitur, kreditor dan kejaksaan dll. Pengajuan kepailitan memiliki potensi terjadinya tidakan fraud didalamnya. Sebagai contoh yaitu pengajuan pailit yang dilakukan oleh kejaksaan dapat disebabkan karena tindakan fraud yang dilakukan pemilik perusahaan. Informan 3 mengungkapkan 
mengenai tindakan fraud yang dilakukan debitur pada umumnya dengan membawa lari uang hasil pinjaman, berikut ini adalah kutipan hasil wawancaranya : "Fraud yang dilakukan oleh debitur adalah dengan membawa lari uang para kreditur,dimana debitur meminjam uang kepada banyak kreditur kemudian dia melarikan diri dengan membawa seluruh uang kreditur sehingga pada akhirnya perusahaan tidak dapat beroperasi dan bankruptcy karena ditinggalkan oleh pemiliknya”.

Kondisi diatas mencerminkan bahwa tindakan fraudyang dilakukan pada akhirnya menyebabkan kebangkrutan perusahaan. Dalam kondisi tersebut maka dapat diajukan proses kepailitan oleh Kejaksaaan. Pasal 2 ayat (2) UndangUndang No. 37 Tahun 2004 menentukan bahwa permohonan pernyataan pailit dapat diajukan oleh kejaksaan untuk kepentingan umum. Maksud dari kepentingan umum adalah kepentingan bangsa dan negara dan/atau kepentingan masyarakat luas, misalnya debitur melarikan diri, debitur menggelapkan bagian dari harta kekayaan, debitur mempunyai utang kepada Badan Usaha Milik Negara atau badan usaha lain yang menghimpun dana dari masyarakat, debitur mempunyai utang yang berasal dari penghimpunan dana dari masyarakat luas, debitur tidak beritikad baik atau tidak koperatif dalam menyelesaikan masalah utang-piutang yang telah jatuh waktuataudalam hal lainnya menurut kejaksaan merupakan kepentingan umum.

Hal tersebut senada dengan yang diungkapkan informan 3; bahwa tindakan fraud dapat menyebabkan kebangkrutan suatu perusahaan : “Banyak kasus kecurangan yang dilakukan perusahaan yang akhirnya menyebabkan perusahaan bangkrut, seperti yang terjadi pada kasus satyam pada tahun 2009 an di India, pimpinan perusahaan tersebut mengakui tindakan kecurangan dengan melakukan pemalsuan atas saldo kas, sehingga perusahaan tersebut menjadi bankrupt padahal tahun 2010 perusahaan tersebut sudah mendapatkan kontrak menjadi IT system untuk piala dunia”.

Kecurangan yang dilakukan perusahaan pada akhirnya dapat menyebabkan kerugian bagi perusahaan yaitu berada dalam kondisi bangkrut, dikarenakan reputasi perusahaan yang menurun akibat tindakan tersebut. Berdasarkan pernyataan perusahaan yang melakukan tindakan fraud dapat menurunkan kepercayaan publik atau citra perusahaan sehingga pada akhirnya perusahaan tersebut akan bankrupt.

\section{Bankruptcy/Kepailian Digunakan untuk Melakukan Fraud}

Pengajuan kepailitian yang dilakukan oleh debitur, didalamnya berpotensi terjadinya tindakan fraud yaitu dengan cara mengecilkan jumlah asset yang dimiliki dalam laporan keuangan ketika kurator masuk keperusahaan untuk mengurus budel (asset) pailit. Seperti yang diungkapkan informan 3: "Ketika kurator masuk,sangat memungkinkan debitur menyembunyikan sejumlah kas atau deposito yang dimiliki perusahaan yang segera dialihkan oleh direktur perusahaan ke rekening orang terdekat ataukeluarga jauh. Seperti yang pernah terjadi, bahwa seorang klien dalam penugasan audit investigatifbankruptcy menyembunyikan sejumlah dana yang cukup besar dalam deposito”. Hal senada diungkapkan informan 1 mengenai kemungkinan tindakan fraud oleh debitur serta hambatan dalam melakukan pengurusan budel (harta) pailit, Karena potensi fraud terjadi didalamnya. Seperti pernyataan yangdikutip dari informan 1: "Kemungkinan fraud itu selalu ada. Itu biasanya debitur yang nakal.dia berusaha untuk mengamankan hartanya. Sebelum kurator bergerak, mungkin dia membayar utang ke orang yang belum jatuh tempo atau dia alihkan ke luar negeri. Itu kan dia mencoba untuk mengamankan aset dia.Hambatannya namanya orang kaya karyawan lah. Kita dikerjai oleh karyawan. Kalau kuratorkan yang penting gimana budel pailit ini jadi besar dan aman. Sedangkan mereka mau hak, "hak saya mana” gitu. Kita mau menjalankan mesin atau mengambil mesin, mereka pasti menghalangi. Banyak lah temen-temen yang dikurung, dikejar anjing, saya masuk ruangan anjing dilepas. Wah itu banyak, ada yang kapok, karena kan yang namanya orang kalau masalah uang harus dia dapet, sedangkan kedudukan kreditor kan kalau yang preferen aman tapi kalo kongruenkan paling terakhir diberikan sisa budel pailit setelah kreditur preferen. Kurator harus atau asset perusahaan ada dimana, karena kalau tidak tau bisa bisa jebol budel pailitnya”.

Hal senada diungkapkan informan 2 yang berprofesi sebagai akuntan forensik, bahwa tindakan fraud dilakukan oleh debitur setelah dinyatakan pailit diantaranya adalah: "Setelah suatu perusahaan dinyatakan pailit sangat mungkin terjadinya transfer dana kepada pemegang saham tertentu yang merupakan tindakan fraud yang dilakukan pimpinan tertinggi perusahaan guna mengalihkan dana agar tidak ikut serta dalam harta pailit atau dengan cara menjual inventory perusahaan dan hasil penjualannya masuk ke rekening pribadi pemilik, pembayaran 
dengan jumlah yang besar kepada vendor yang tidak biasa”.

Fraudulent concealment atas asset dan pendapatan merupakan hal yang sering dilakukan, seperti yang diungkapkan Fraudulent concealment of assets or income is a common fraud in both bankruptcy and divorce. Hal ini memunjukan bahwa terjadi fraud pada kondisi bankrupt pada umumnya adalah dengan merahasiakan asset ataupun pendapatan yang diperoleh perusahaan.

Selain proses pengajuan kepailitan yang dilakukan oleh debitur, maka proses pengajuan kepailitan ke Pengadilan Niaga dapat diajukan oleh kreditor. Potensi tindakan fraud dapat terjadi dalam pengajuan tersebut, seperti yang diungkapkan oleh informan 1: "Pengajuan pailit yang dilakukan krediturpun dapat berpotensi munculnya tindakan fraud dengan motif untuk menguntungkan kreditur. Jika ada 2 kreditor maka dapat diajukan pailit ke Pengadilan Niaga dan harus dibuktikan apakah dia benar pailit atau tidak. Persidangan harus membuktikan bahwa debitur benar benar insolved atau tidak. Nah jika belum benar benar bangkrut dan selama debitur masih bisa membayar utang, hanya terhambat pembayaran saja kan tidak bisa diputuskan pailit. Dalam kondisi pailit diajukan kreditur, maka debitur harus pintar membuktikan bahwa dia tidak dalam keadaan bangkrut,debitur harus sadar bahwa asset yang dimiliki banyak dan piutang diluar banyak, hanya tidak mampu membayar hutang jatuh tempo pada minimal 2 kreditur saja,sehingga kondisi tersebut dapat dimanfaatkan pula oleh kreditur nakal”.

\section{Kepailitan/Bankruptcy Digunakan untuk} Menyembunyikan Fraud.

Kondisi lainnya yang terjadi adalah bahwa terjadinya fraud disembunyikan melalui upaya proses pengajuan kepailitan. Seperti yang diungkapkan oleh informan 3 berikut ini: "Tindakan fraud yang dilakukan oleh orang dilingkungan organisasi dengan pihak lainnya diluar organisasi dapat disembunyikan melalui proses kepailitan. Sebagai contoh pemberian kredit tidak sesuai prosedur atau fiktif dapat menyebabkan pembiayaan bermasalah. Untuk menyembunyikan tindakan fraud atau pemberian kredit tersebut maka perusahaan penerima pinjaman dana dapat menyatakan dirinya pailit. Sehingga dalam hal ini kedua pihak yang melakukan fraud dapat menyembunyikan fraud.

Upaya penyembunyian fraud dengan skema kebangkrutan ini pada umumnya juga dilakukan oleh debitur dengan cara merusak buku dan catatan keuangannya atau mencatat transaksi keuangan dengan tidak tepat. Hal tersebut sangat mungkin terjadi apabila aparat penegakan hukum di Pengadilan Niaga tidak berjalan dengan efektif yang pada akhirnya dapat menyatakan pailit suatu kasus dalam kondisi terdapat banyak fraud di dalamnya. Ketiga kategori mengenai fraud yang terjadi dalam kondisi bangkrut, seperti yang dijelaskan pada paragraph sebelumnya sesuai dengan pernyataan yang mengkategorikan tindakan fraud in bankruptcy and divorce menjadi 3 hal yaitu : 1) fraud causes the bankruptcy or divorce; 2) the bankruptcy or divorce is used to perpetrate the fraud; 3) the bankruptcy or divorce is used to conceal the fraud.

\section{SIMPULAN DAN SARAN}

Berdasarkan hasil pembahasan yang dilakukan pada Bab sebelumnya dalam artikel ini sehingga ditarik kesimpulan dan saran - saran yang mungkin berguna dan bermanfaat di masa yang akan datang maka diambil beberapa kesimpulan berikut ini:

1. Pengajuan tindakan kepailitan dapat dilakukan dengan syarat apabila terdapat utang kepada dua atau lebih kreditor yang telah jatuh tempo akan tetapi tidak dapat dilunasi oleh debitur, dimana debitur harus dalam keadaan insolvent, yaitu tidak membayar lebih dari 50\% utang-utangnya. Pengajuan kepailitan dilakukan pada Pengadilan Niaga yang melibatkan hakim pengawas dan kurator. Dalam menentukan keabsahan utang piutang oleh seorang hakim pengawas digunakan ilmu akuntansi forensik, begitupula dengan kurator yang bertugas untuk membagikan budel (harta) pailit kepada para kreditur dengan urutan pembagian harta bagi kreditor separatis (kreditor yang memiliki jaminan), kreditor preferen (kreditur yang memiliki hak untuk didahulukan) dan kreditor kongruen (kreditur yang tidak memiliki jaminan).

2. Pengajuan kepailitan dapat dilakukan oleh 3 (tiga) pihak yaitu debitur, kreditor dan lain-lain. Pengajuan kepailitan berpotensi terdapat tidakan fraud didalamnya, kategori tindakan fraud dalam kepailitan dibagi menjadi 3 (tiga) hal Pertama yaitu fraud yang menyebabkan terjadinya bankrupt; dalam kondisi ini tindakan fraud yang dilakukan dalam suatu perusahaan akan menurunkan kepercayaan publik sehingga pada akhirnya perusahaan akan mengalami kebangkrutan. Kedua bankrupt digunakan untuk melakukan fraud; hal ini bisa dilakukan oleh kreditor maupun debitur. Pada umunya tindakan fraud yang dilakukan debitur adalah dengan menyembunyikan aset dan penjualan sedangkan tindakan fraud yang 
dilakukan adalah dengan motif untuk memperoleh budel (harta) pailit. Dan Ketiga bankrupt digunakan untuk menyembunyikan fraud; kondisi ini pada umumnya dilakukan debitur dengan cara menghilangkan dokumen dan catatan perusahaan agar tindakan fraud yang dilakukan dapat tertutupi dengan mempailitkan perusahaan.

3. Peran pemerintah dalam membuat kebijakan (regulasi) untuk memberantas korupsi dan kecurangan nampak dengan menerbitkan beberapa regulasi dan peraturan perundangan terkait dengan pemberantasan korupsi dan kecurangan, selain itu dengan dibentuknya KPK melalui regulasi khusus yang merupakan sebuah lembaga super body dengan kewenangan luar biasa diharapkan mampu mendukung pemerintah dalam upaya pemberantasan korupsi dan kecurangan di Indonesia.

\section{DAFTAR PUSTAKA}

Adrian Sutedi, 2009, “Hukum Kepailitan”, Cetakan Pertama, Ghalia Indonesia, Bogor.

Aryani Widyawati, 2012, Konstruksi Sosial. Intellectual Capital: Studi Atas Keberadaan Intellectual Capital Dan Pengungkapannya Pada Bank Jateng, Skripsi Fakultas Ekonomika Dan Bisnis Universitas Diponegoro Semarang.

Burrel, G. dan G. Morgan. 1979. Sociological Paradigms and Organisational Analysis. Ashgate Publishing Company, USA.

Budianto, I.M. 2002. Realitas dan Obyektifitas. Penerbit Wedatama Widya Sastra. Jakarta. Bruno Maria Franceschetti \& Claudia Koschtial, 2013. Do bankrupt companies, manipulate earnings more than the non-bankrupt ones?, University of Macerata, Italy Technische Universität Bergakademie Freiberg,Germany, P.1, Journal of Finance and Accountancy.

Chua, W.F. 1986. Radical Developments in Accounting Thought. The Accounting Review. Vol. 61, No. 4 (Oct); 601-632.

Coram, P. Ferguson, C. dan Moroney, R. 2008. Internal audit, alternative internal audit tructures and the level of misapropriation of assets fraud. Accounting and Finance vol. 48.

F. Laela, 1997. Transformasi Tanggung Jawab Profesi Akuntansi dalam Memasuki Millenium Kedua,
Journal of Accounting and Auditing.

Hogan, C. E., Z. Rezaee., R. A. Riley., dan U. K. Velury. 2008. Financial Statement Fraud: Insights From The Academic Literature. Auditing: A Journal of Practice and Theory vol 27.

Imang Dapit Pamungkas Ph.D, Imam Ghozali, and Tarmizi Achmad, 2017, The Effects Of The Whistleblowing System On Financial Statements Fraud: Ethical Behavior As The Mediators Student At Faculty Of Economics And Business, Diponegoro University, Indonesia Lecturer At Faculty Of Economics And Business Pekalongan University, Indonesia, International Journal of Civil Engineering and Technology (IJCIET) Volume 8, Issue 10, October 2017, pp. 1592-1598, Article ID: IJCIET_08_10_159 Available online at http://www.iaeme.com/ijciet/ issues.asp? JType $=$ IJCIET\&VType $=8 \&$ IType $=10$ ISSN Print: 0976-6308 and ISSN Online: 0976-6316. Jumansyah, dkk. 2011. Akuntansi Forensik dan Prospeknya Terhadap Penyelesaian MasalahMasalah Hukum di Indoesia. Prosiding Seminar Nasional" Problematika Hukum dalam Implementasi Bisnis dan Investasi (Prespektif Multidisipliner)”.

NH.Nimastuti, 2005. Faktor-faktor yang Mempengaruhi Minat Mahasiswa Akuntansi untuk Mengikuti Pendidikan Profesi (PPA), FEB Universitas Diponegoro.

Puspasari, Novita,. Dan Eko Suwardi. 2014. Pengaruh Moralitas Individu dan Pengendalian Internal Terhadap Kecenderungan Kecurangan Akuntansi. Jurnal Akuntansi. Yogyakarta: Universitas Gadjah $\mathrm{M}$ a d a . D i d a p a t k a $\mathrm{n}$ : (diakses 18 Juli 2017).

Rachmadi Usman, 2004, Dimensi Hukum Kepailitan di Indonesia, PT. Gramedia Pustaka Utama, Jakarta, hlm.12

Salim, A. 2001. Teori dan Paradigma Penelitian Sosial (dari Denzin Guba dan Penerapannya). Tiara Wacana, Yogyakarta.

Triyuwono, I. 2012. Akuntansi Syari'ah: Perspektif, Metodologi, dan Teori. Edisi ke-3. PT Raja Grafindo Persada, Jakarta.

Tuanakotta, 2016. Akuntansi Forensik dan Audit Investigasi, edisi ketiga, Unversitas Indonesia Jakarta.

Wells, J. T. 2007. Corporate Fraud Handbook: Prevention and Detection: Second Edition. John Wiley and Sons Inc. 